\title{
PENGARUH LATIHAN BEBAN TERHADAP KEKUATAN OTOT LANSIA
}

\author{
${ }^{1}$ Febriani Patandianan R. \\ ${ }^{2}$ Herlina I. S. Wungouw \\ ${ }^{2}$ Sylvia Marunduh
}

\begin{abstract}
${ }^{1}$ Kandidat Skripsi Fakultas Kedokteran Universitas Sam Ratulangi Manado
${ }^{2}$ Bagian Fisiologi Fakultas Kedokteran Universitas Sam Ratulangi Manado

Email: Febypr11_280@yahoo.com
\end{abstract}

\begin{abstract}
Elderly are people who have biological systems changing both functional and structural due to the aging process. They experience a decline usphysical capacity, marked by the decrease. This study aimed to determine the effect of weight training on muscle strength of elderly. This was an experimental study with pre-post test group design. Results and Conclusion: In several movements which are showed a significant $p$ value $=0.000(p<0.005)$ in muscle strength with elbow flexion, elbow extension, and shoulder extension. A significant value of $\mathrm{p}=0.001(\mathrm{p}<0.005)$ is obtained on the movement of shoulder flexion, shoulder abduction, left foot flexion, and right foot extension, another results $p$ value $=0.002(\mathrm{p}<0.005)$ in foot dorsoflexion, and $\mathrm{p}$ value $0.003(\mathrm{p}<0.005)$ on the movements of the left leg extension, leg flexion while dextra obtained significant $\mathrm{p}$ value $=0.004(\mathrm{p}<0.005)$. As a conclusion weight training can strengthen the muscle of elderly.
\end{abstract}

Keywords: weight training, muscle strength, elderly

\begin{abstract}
Abstrak: Lansia merupakan orang yang sistem biologisnya mengalami perubahanperubahan struktur dan fungsi dikarenakan usia yang sudah lanjut. Pada lansia terjadi penurunan kapasitas fisik yang ditandai dengan penurunan massa otot serta kekuatannya yang akan menjadi penghambat dalam melaksanakan aktivitas. Tujuan penelitian ini untuk mengetahui pengaruh latihan beban terhadap kekuatan otot lansia. Penelitian ini bersifat eksperimental dengan rancangan pre-post one group test. Hasil dan simpulan: Hasil penelitian menunjukkan nilai signifikan $p=0,000(p<0,05)$ pada kekuatan otot dengan gerakan fleksi siku, ekstensi siku dan ekstensi bahu. Nilai signifikan $\mathrm{p}=0,001(\mathrm{p}<0,05)$ pada gerakan fleksi bahu, abduksi bahu dan fleksi kaki sinistra, ekstensi kaki dextra, nilai $\mathrm{p}=0,002(\mathrm{p}<0,005)$ pada dorsofleksi kaki dan nilai $\mathrm{p}=0,003(\mathrm{p}<0,05)$ pada gerakan ekstensi kaki sinistra, sedangkan gerakan fleksi kaki dextra diperoleh nilai signifikan $\mathrm{p}=0,004(\mathrm{p}<0,05)$. Pada penelitian ini terdapat pengaruh latihan beban terhadap kekuatan otot lansia.
\end{abstract}

Kata kunci: latihan beban, kekuatan otot, lansia

Lanjut usia (lansia) merupakan proses alami yang tidak dapat dihindari oleh setiap individu. Penuaan (menjadi tua: aging) adalah suatu proses penghilangan secara perlahan-lahan kemampuan jaringan untuk memperbaiki diri atau mengganti diri dan mempertahankan struktur dan fungsi normalnya sehingga dapat bertahan 
terhadap jejas (termasuk infeksi) dan memperbaiki kerusakan yang diderita.Pada tahun 2000, Indonesia merupakan negara urutan ke-4 dengan jumlah lansia paling banyak sesudah Cina, India, dan USA. ${ }^{1,2}$

Perkembangan penduduk lansia di Indonesia menarik untuk diamati, dimana cenderung terjadi peningkatan jumlah lansia dari tahun ke tahun. Kantor Kementerian Koordinator Kesejahteraan Rakyat (KESRA) melaporkan, jika tahun 1980 usia harapan hidup 52,2 tahun dan jumlah lansia 7.998 .543 orang $(5,45 \%)$, maka pada tahun 2006 menjadi 19 juta orang $(8,90 \%)$ dan usia harapan hidup juga meningkat (66,2 tahun). Pada tahun 2010 perkiraan penduduk lansia di Indonesia akan mencapai 23,9 juta atau 9,77 \% dan usia harapan hidup sekitar 67,4 tahun. Badan kesehatan dunia WHO menyatakan bahwa penduduk lansia di Indonesia pada tahun 2020 mendatang diperkirakan mencapai angka 28,8 juta orang atau tercatat $11,34 \%$, dengan usia harapan hidup 71,1 tahun. ${ }^{2,3}$

Peningkatan jumlah lansia di dunia akan bertambah dengan cepat, malahan akan relatif lebih besar di negara-negara sedang berkembang termasuk di Indonesia. Menurut data Bureau of the Cencus USA, dilaporkan bahwa Indonesia akan mengalami kenaikan jumlah lanjut usia sebesar 414\% pada tahun 1990-2025. Angka ini merupakan angka tertinggi di dunia dan menunjukkan bahwa angka harapan hidup di Indonesia meningkat pesat. Peningkatan angka harapan hidup lansia menimbulkan berbagai masalah polemik, seperti masalah sosial, psikologis, dan psikis akibat proses degeneratif pada lansia. $^{2-4}$

Pada lansia terjadi penurunan kapasitas fisik yang ditandai dengan penurunan massa otot serta kekuatannya, laju denyut jantung maksimal, toleransi latihan, dan terjadi peningkatan lemak tubuh. ${ }^{2,5}$ Perubahan fisik karena perubahan komposisi tubuh yang menyertai pertambahan umur umumnya bersifat fisiologis, misalnya turunnya tinggi badan, berat badan, daya lihat, daya dengar, kemampuan berbagai rasa, toleransi tubuh terhadap glukosa, fungsi otak, dan kekuatan otot. ${ }^{6}$ Kualitas fisik yang kurang baik akan menjadi penghambat dalam melaksanakan aktivitas sehari-hari serta massa otot dan kekuatan otot akan menjadi lemah. Kelemahan otot pada lansia akan berdampak pada keseimbangan yang berimplikasi terhadap timbulnya gangguan menjalankan mobilitas fungsional sehingga meningkatkan risiko tejadinya jatuh yang menyebabkan ketergantungan dalam menjalankan aktivitas sehari-hari. Sebesar 28-35\% lansia di atas 65 tahun setidaknya jatuh satu kali dalam satu tahun dan meningkat pada usia di atas 75 tahun sebesar 32-42\%. Jadi, sangat penting bagi lansia untuk menjaga dan memelihara kekuatan otot. $^{7}$

Olahraga merupakan alternatif yang efektif dan aman untuk meningkatkan atau mempertahankan kebugaran dan kesehatan jika dikerjakan secara benar. ${ }^{12}$ Salah satu komponen dari kebugaran yang terkait dengan kesehatan umum ialah kekuatan otot. Penelitian yang dilakukan tahun 2011 pada lansia (usia di atas 60 tahun) yang melakukan latihan kekuatan menyatakan bahwa latihan kekuatan meningkatkan kekuatan otot dengan meningkatkan massa otot. Massa otot dapat ditingkatkan melalui pelatihan intensitas $60 \%$ sampai $85 \%$ dari kekuatan maksimum. Latihan kekuatan memiliki efek positif terhadap gangguan kardiovaskuler, diabetes dan osteoporosis. Penelitian yang dilakukan oleh Lee dan Park tahun 2013 menyatakan bahwa latihan kekuatan tidak hanya meningkatkan kekuatan tetapi juga meningkatkan keseimbangan lansia. ${ }^{9,10}$ Berdasarkan uraian di atas, peneliti tertarik untuk mengetahui pengaruh latihan beban terhadap kekuatan otot lansia.

\section{METODE PENELITIAN}

Metode penelitian ini merupakan penelitian eksperimental dengan rancangan pre-post one group test. Penelitian dilakukan di Balai Penyantunan Lanjut Usia (BPLU) Senja Cerah Manado. Waktu penelitian selama Oktober 2014 sampai 
Januari 2015.

Populasi penelitian adalah lansia di BPLU Senja Cerah. Sampel penelitian merupakan populasi lansia yang memenuhi kriteria inklusi. Kriteria inklusi pada penelitian ini berusia di atas 60 tahun dan bersedia menjadi responden dan mengisi informed consent sedangkan kriteria eksklusi yaitu sakit sendi. Variabel bebas penelitian yaitu latihan beban pada lansia dan variabel terikat yaitu kekuatan otot

Lansia adalah orang yang berusia di atas 60 tahun. Proses latihan yang dilakukan secara teratur, berulang pada orang yang berusia di atas 60 tahun dengan menggunakan beban. Kekuatan otot diukur berdasarkan 1 repetition maximum. Instrumen penelitian yaitu beban,alat tulis, buku, komputerdan literatur.

Latihan beban dilakukan 3 kali seminggu selama satu bulan. Setiap responden ditentukan beban maksimum dengan teknik 1 repetition maximum untuk tiap gerakan. Pengukuran kekuatan otot lansia dilakukan dengan menentukan beban maximum yang dapat diangkat 1 kali melawati sebuah lingkup gerak sendi. Latihan ini berupa lima gerakan tangan yaitu fleksi siku, ekstensi siku, fleksi bahu, ekstensi bahu dan abduksi serta tiga gerakan kaki yaitu fleksi kaki, ekstensi kaki, dan dorsofleksi. Latihan beban pada minggu pertama dilakukan dengan menggunakan 50\% dari berat beban maximum yang dapat diangkat oleh responden dengan 1 kali melewati lingkup gerak sendi. Pada minggu berikutnya dilakukan latihan dengan beban maximum yang dapat diangkat oleh responden. Satu bulan kemudian, responden dikumpulkan untuk dilakukan pengukuran kekuatan otot sebagai post test dengan metode yang sama.

Data dianalisis dengan uji $\mathrm{T}$ berpasangan untuk mengetahui ada tidaknya perbedaan antara kekuatan otot sebelum dan sesudah latihan beban pada lansia. Uji statistik dijalankan dengan menggunakan perangkat lunak SPSS (Statistical Product and Service Solutions) versi 20.0 .

\section{HASIL PENELITIAN}

Penelitian mengenai pengaruh latihan beban terhadap kekuatan otot lansia dilakukan pada Oktober 2014 sampai dengan Januari 2015 di BPLU Senja Cerah Manado. Sebelum melakukan penelitian, peneliti terlebih dahulu meminta izin kepada kepala BPLU untuk melakukan penelitian dengan membawa surat izin penelitian yang dikeluarkan dari bagian Fisiologi Fakultas Kedokteran Universitas Sam Ratulangi. Setelah mendapatkan izin, peneliti kemudian melakukan sosialisasi kepada lansia yang berada di BPLU Senja Cerah.

Pada penelitian ini diperoleh sebanyak 26 subjek yang diambil dari sebagian populasi yang telah memenuhi kriteria inklusi. Sebelas subjek dieksklusi karena subjek tersebut tidak mengikuti penelitian sampai selesai sehingga sampel penelitian menjadi 15 subjek.

Tabel 1. Distribusi lansia berdasarkan umur

\begin{tabular}{ccc}
\hline Umur (tahun) & Frekuensi & $\begin{array}{c}\text { Presentase } \\
(\%)\end{array}$ \\
\hline Elderly (60-74) & 8 & 53,3 \\
Old (75-90) & 7 & 46,7 \\
\hline
\end{tabular}

Pada Tabel 1 pengelompokan usia menggunakan pembagian menurut WHO, dari 15 orang lansia yang menjadi subjek penelitian, sebanyak delapan (53,3\%) lansia berusia 60 sampai 74 tahun termasuk kelompok elderly, sedangkan tujuh (46,7\%) lansia berusia antara 75 sampai 90 tahun termasuk kelompok old. Subjek penelitian ini dominan berumur 60-74 tahun (old).

Tabel 2. Distribusi lansia berdasarkan jenis kelamin

\begin{tabular}{ccc}
\hline Jenis Kelamin & Frekuensi & $\begin{array}{c}\text { Presentase } \\
(\%)\end{array}$ \\
\hline Laki-laki & 5 & 33,3 \\
Perempuan & 10 & 66,7 \\
\hline
\end{tabular}

Pada Tabel 2 dapat dilihat dari 15 lansia yang menjadi subjek penelitian, sebanyak lima orang $(33,3 \%)$ laki-laki dan 
10 orang $(66,7 \%)$ perempuan.

Berdasarkan Gambar 1, didapatkan rata-rata kekuatan otot pada kelompok umur elderly dengan gerakan fleksi siku dextra sebelum latihan 2,84 dan setelah latihan 3,91, gerakan fleksi siku sinistra sebelum latihan 2,72 dan setelah latihan 3,78 , gerakan ekstensi siku dextra sebelum latihan 2,78 dan setelah latihan 3,97, kekuatan otot pada gerakan ekstensi siku sinistra sebelum latihan 2,69 dan setelah latihan 3,72.

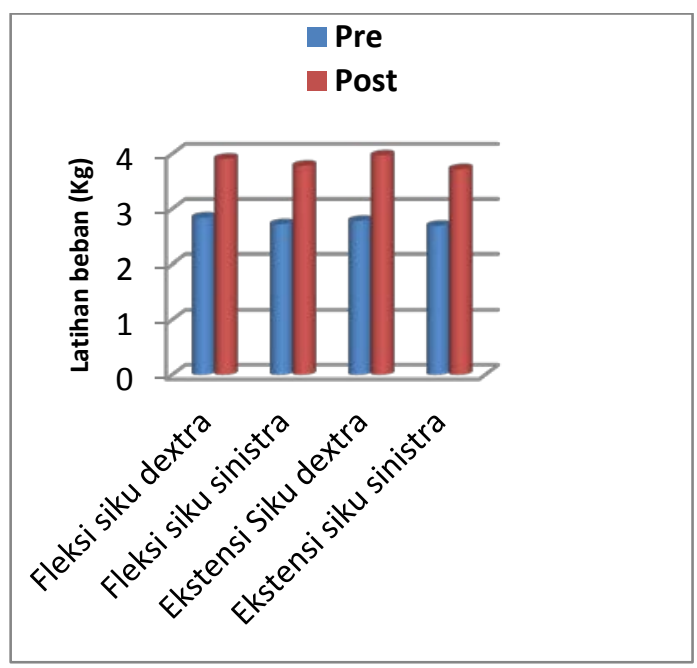

Gambar 1. Rata-rata kekuatan otot siku pada elderly

Pada Gambar 2 dengan kelompok umur old dapat dilihat bahwa sebelum latihan kekuatan otot dengan gerakan fleksi siku dextra 2,25 dan setelah latihan mengalami peningkatan 2,93. Kekuatan otot pada gerakan fleksi siku dextra mengalami peningkatan dari 2,07 menjadi 2,71, gerakan ekstensi siku dextra dari 2,04 menjadi 2,86 dan pada gerakan ekstensi siku sinistra dari 1,93 menjadi 2,71.

Gambar 3 menunjukkan rata-rata kekuatan otot dengan gerakan siku pada kelompok umur elderly. Kekuatan otot fleksi bahu dextra sebelum latihan 2,25 menjadi 2,75. Kekutan otot fleksi bahu sinistra sebelum latihan 2,13, menjadi 2,63. Gerakan ekstensi bahu dextra sebelum latihan 2,63 mengalami peningkatan menjadi 3,72. Gerakan ekstensi sinistra dari 2,56 menjadi 3,69. Gerakan abduksi dextra dari 2,5 menjadi 3,34 Abduksi sinistra sebelum latihan 2,41, menjadi 3,09.

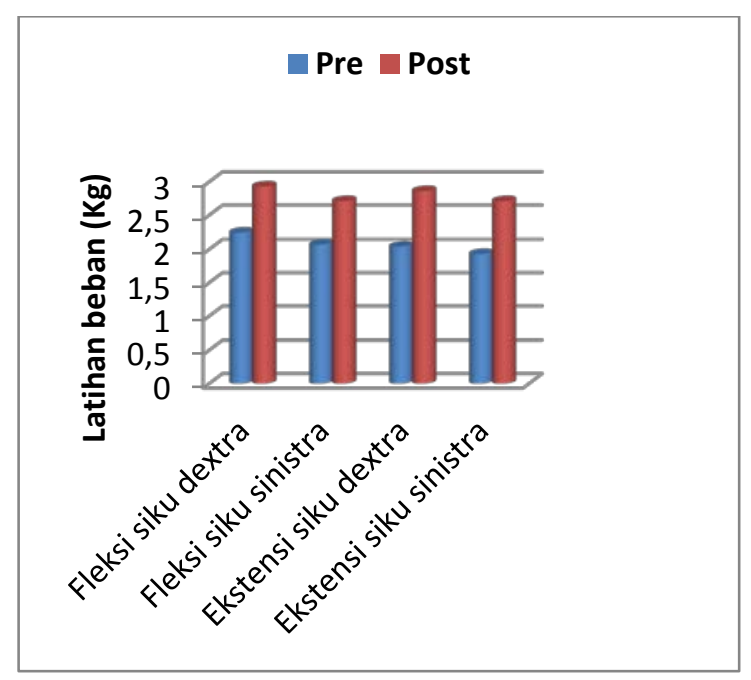

Gambar 2. Rata-rata kekuatan otot siku pada old

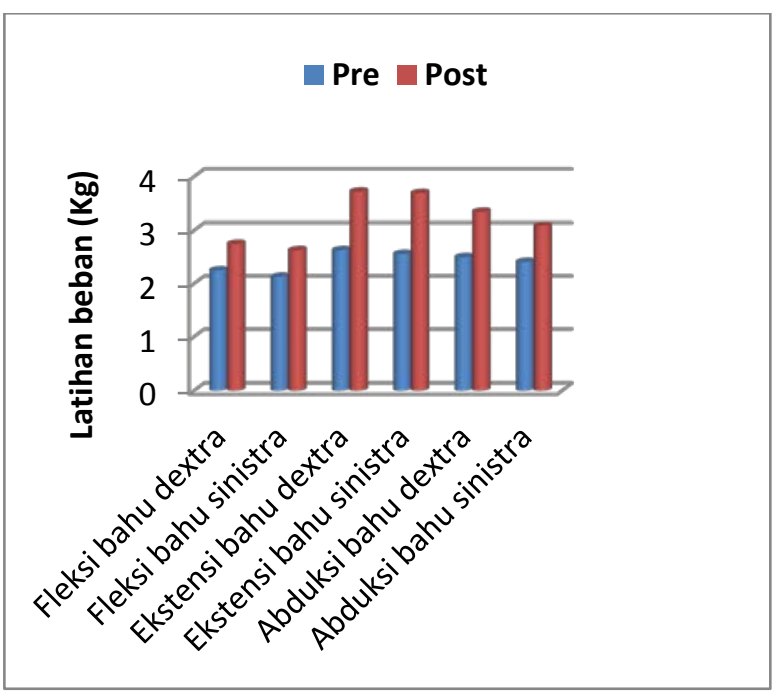

Gambar 3. Rata-rata kekuatan otot bahu pada elderly

Gambar 4 menunjukkan sebelum latihan rata-rata kekuatan otot fleksi bahu dextra 1,68, fleksi bahu sinistra 1,39, ekstensi dextra 2, ekstensi sinistra 1,68, abduksi dextra 2,04, dan abduksi sinistra 1,64. Setelah latihan kekuatan otot fleksi bahu dextra 2,11, fleksi bahu sinistra 1,86, ekstensi dextra 2,79, ekstensi sinistra 2,46, abduksi dextra 2,32, dan abduksi sinistra 2,11.

Pada Gambar 5, dapat dilihat rata-rata kekuatan otot pada kelompok umur elderly. 
Rata-rata kekuatan otot fleksi kaki dextra sebelum latihan 1,84 menjadi 2,47 setelah latihan, fleksi sinistra dari 1,75 menjadi 2,69, gerakan ekstensi dextra dari 2,03 menjadi 2,72, ekstensi sinistra dari 2,16 menjadi 2,88, dorsofleksi dextra dari 1,53 menjadi 1,97 dan dorsofleksi sinistra dari 1,38 mengalami peningkatan menjadi 1,81 .

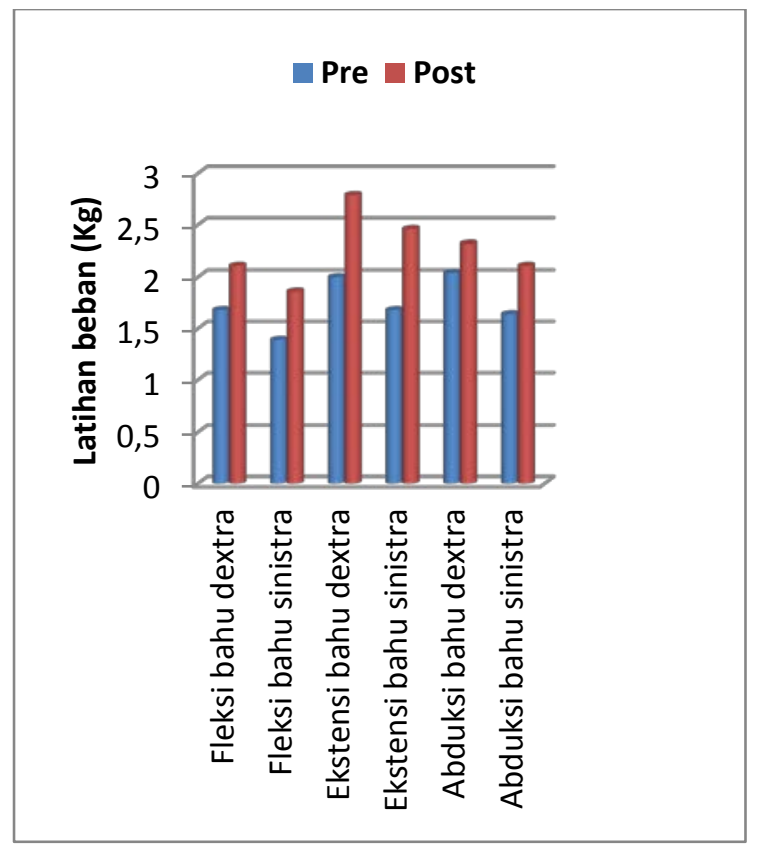

Gambar 4. Rata-rata kekuatan otot bahu pada old

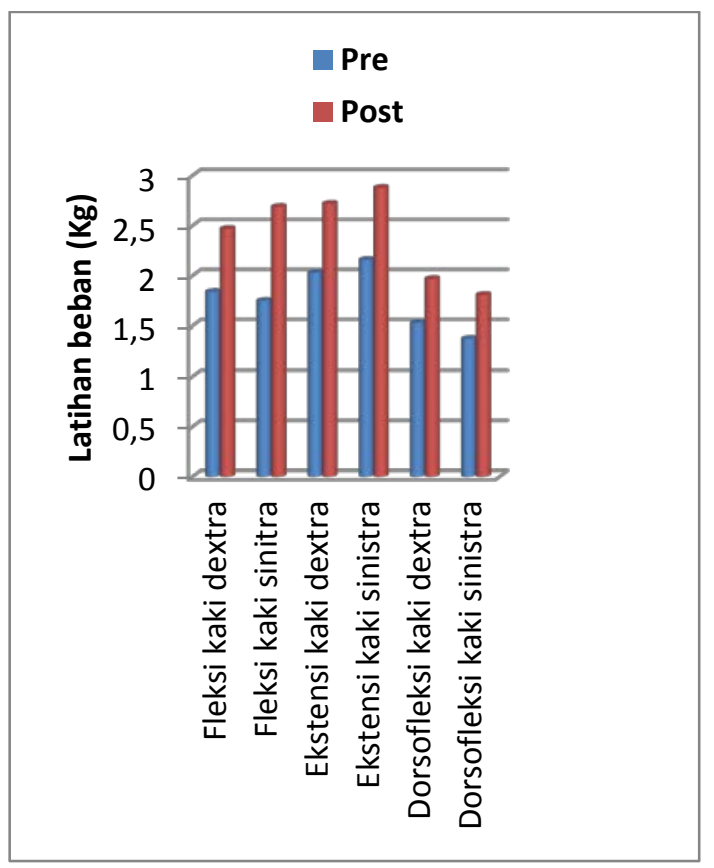

Gambar 5. Rata-rata kekuatan otot kaki pada elderly

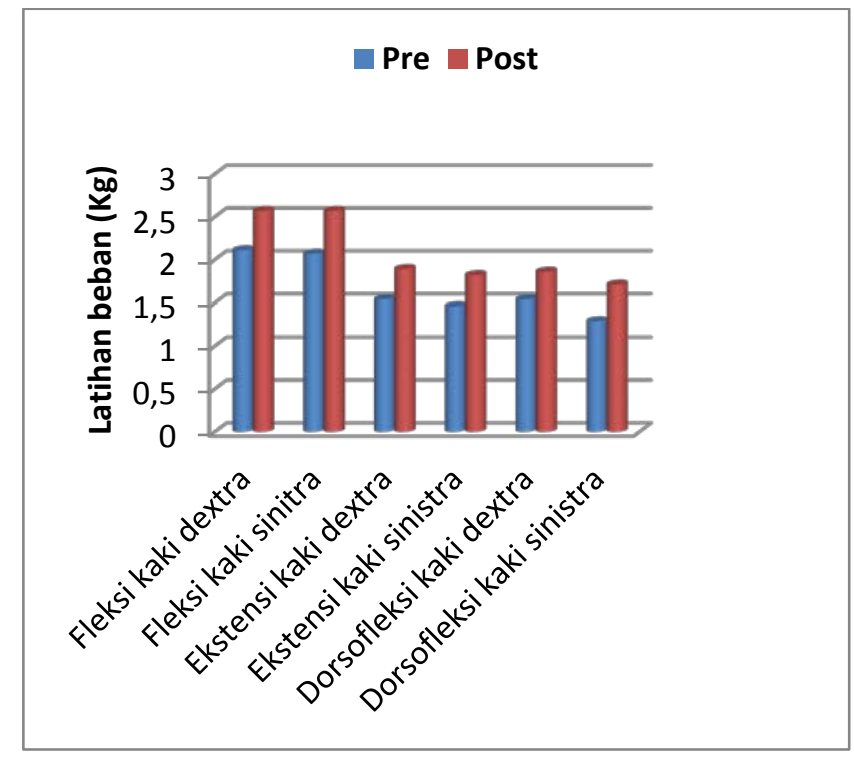

Gambar 6. Rata-rata kekuatan otot kaki pada old

Berdasarkan Gambar 6, dapat dilihat rata-rata kekuatan otot pada kelompok umur old Sebelum latihan, rata-rata kekuatan otot fleksi dextra 2,11, fleksi sinistra 2,07, ekstensi dextra 1,54, ekstensi sinistra 1,46, dorsofleksi dextra 1,54, dan dorsofleksi sinistra 1,29. Setelah latihan rata-rata kekuatan otot fleksi dextra dan sinistra 2,57, ekstensi dextra 1,89, ekstensi sinistra 1,82, dorsofleksi dextra 1,86 dan dorsofleksi sinistra 1,71.

Gambar 7 menunjukkan pada laki-laki rata-rata kekuatan otot fleksi siku dextra 2,35, sedangkan rata-rata kekuatan otot fleksi sinistra, ekstensi dextra dan sinistra yaitu 2,25. Setelah latihan rata-rata kekuatan otot fleksi dextra dan sinistra, ekstensi dextra sama yaitu 3,05, sedangkan ekstensi sinistra 2,95.

Pada Gambar 8 dapat dilihat terjadi peningkatan kekuatan otot setelah latihan beban. Sebelum latihan beban rata-rata kekuatan otot fleksi dextra 2,68 dan setelah latihan 3,65. Sebelum latihan rata-rata kekuatan otot pada fleksi sinistra 2,5 dan setelah latihan beban menjadi 3,4. Rata-rata kekuatan otot pada ekstensi dextra sebelum latihan 2,53 dan setelah latihan 3,65. Sebelum latihan, rata-rata kekuatan otot pada ekstensi sinistra 2,38 dan setelah latihan beban menjadi 3,4 . 


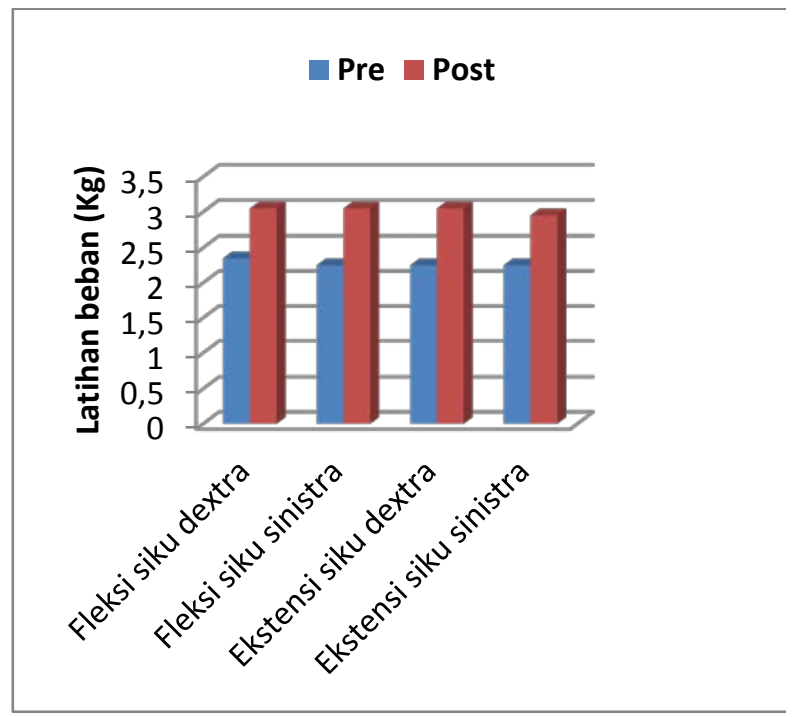

Gambar 7. Rata-rata kekuatan otot siku pada laki-laki

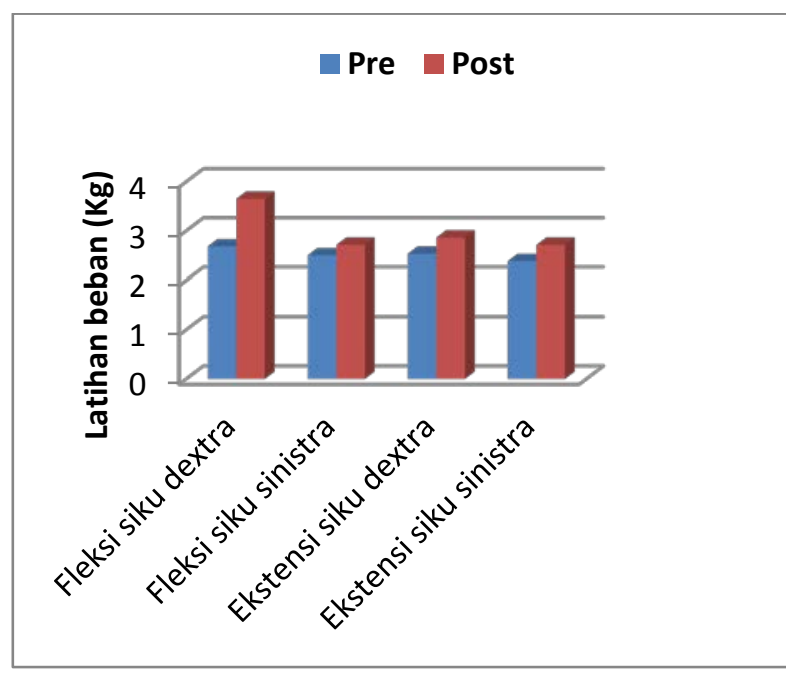

Gambar 8. Rata-rata kekuatan otot siku pada perempuan

Berdasarkan Gambar 9, dapat dilihat bahwa rata-rata kekuatan otot fleksi bahu dextra sebelum latihan 1,7 dan setelah latihan beban mengalami peningkatan menjadi 2,2. Rata-rata kekuatan otot fleksi sinistra sebelum latihan 1,6 , setelah latihan mengalami peningkatan menjadi 2,15.

Peningkatan kekuatan otot juga terjadi pada gerakan ekstensi dan abduksi bahu. Sebelum latihan rata-rata kekuatan otot ekstensi dextra 2,05 dan setelah latihan menjadi 2,75. Pada ekstensi sinistra, sebelum latihan 2 dan setelah latihan menjadi 2,8. Pada gerakan abduksi dextra dari 2,1 menjadi 2,6, sedangkan abduksi sinistra dari 1,9 menjadi 2,75.

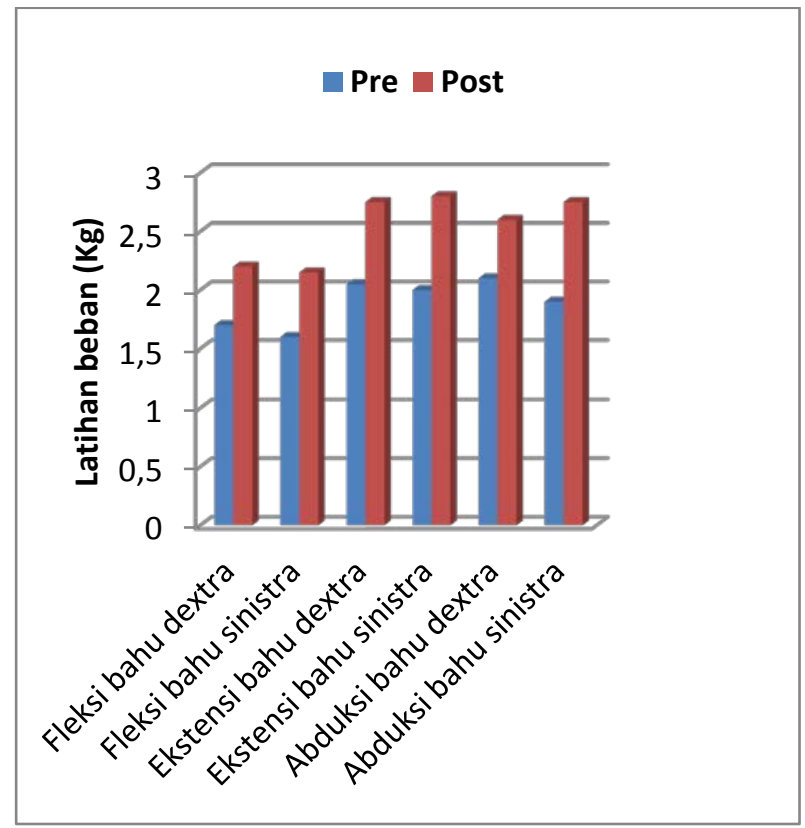

Gambar 9. Rata-rata kekuatan otot bahu pada laki-laki

Pada Gambar 10 menunjukkan ratarata kekuatan otot bahu pada perempuan dengan gerakan fleksi, ekstensi, dan abduksi bahu. Sebelum melakukan latihan beban, rata-rata kekuatan otot pada fleksi dextra 2,13, fleksi sinistra 1,88, ekstensi dextra 2,48, ekstensi sinistra 2,23, abduksi dextra 2,38, dan abduksi sinistra 2,13.

Setelah melakukan latihan beban terjadi peningkatan rata-rata kekuatan otot pada fleksi, ekstensi dan abduksi bahu. Kekuatan otot setelah latihan, fleksi bahu dextra 2,58, fleksi sinistra 2,33, ekstensi dextra 3,55 , ekstensi sinistra 3,28 , abduksi dextra 3, abduksi sinistra 2,58.

Gambar 11 menunjukkan rata-rata kekuatan otot fleksi dextra dan sinistra sebelum latihan yaitu 1,7, ekstensi dextra 1,65, ekstensi sinistra 1,85, dorsofleksi dextra 1,25, dan dorsofleksi sinistra 1,5.Setelah latihan terjadi peningkatan kekuatan otot pada fleksi, ekstensi dan dorsofleksi kaki. Rata-rata kekuatan otot pada fleksi dextra 2,45, fleksi sinistra 2,8, ekstensi dextra 2,25, ekstensi sinistra 2,6, dorsofleksi dextra 1,8 dan dorsofleksi kaki sinistra 1,6.

Berdasarkan Gambar 12 dapat dilihat bahwa pada perempuanterjadi peningkatan rata-rata kekuatan otot dengan gerakan 
fleksi, ekstensi, dorsofleksi kaki pada kelompok umur old. Sebelum latihan, ratarata kekuatan otot fleksi dextra 2,1, fleksi sinistra 2, ekstensi dextra 1,88 , ekstensi sinistra 1,83, dorsofleksi dextra 1,68, dan dorsofleksi sinistra 1,53. Setelah latihan rata-rata kekuatan otot fleksi dextra dan sinistra 2,55, ekstensi dextra 2,38, ekstensi sinistra 2,28, dorsofleksi dextra 1,98 dan dorsofleksi sinistra 1,85.

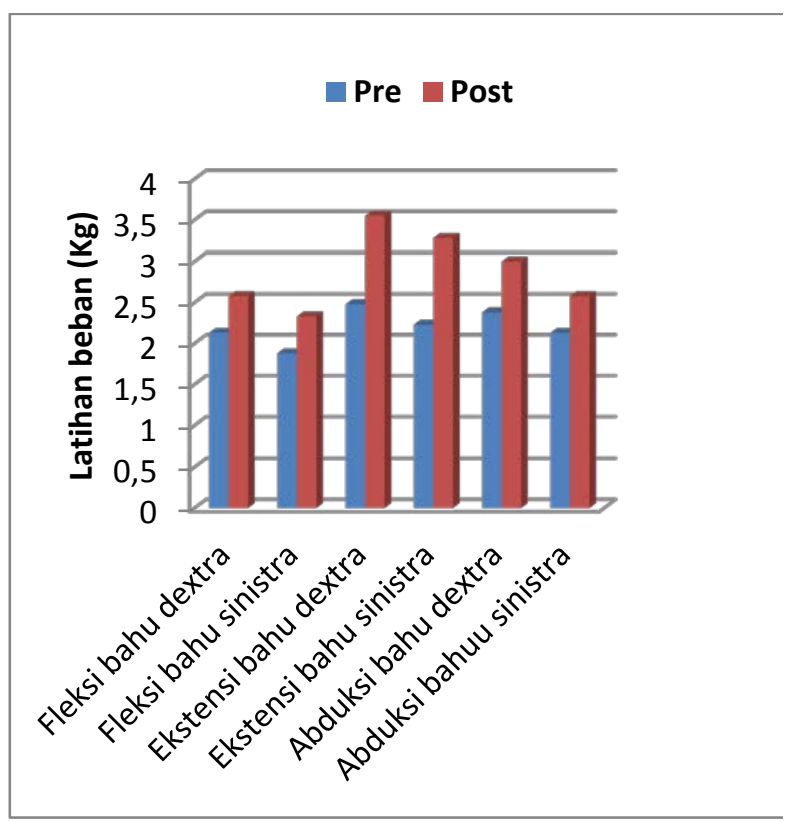

Gambar 10. Rata-rata kekuatan otot bahu pada perempuan

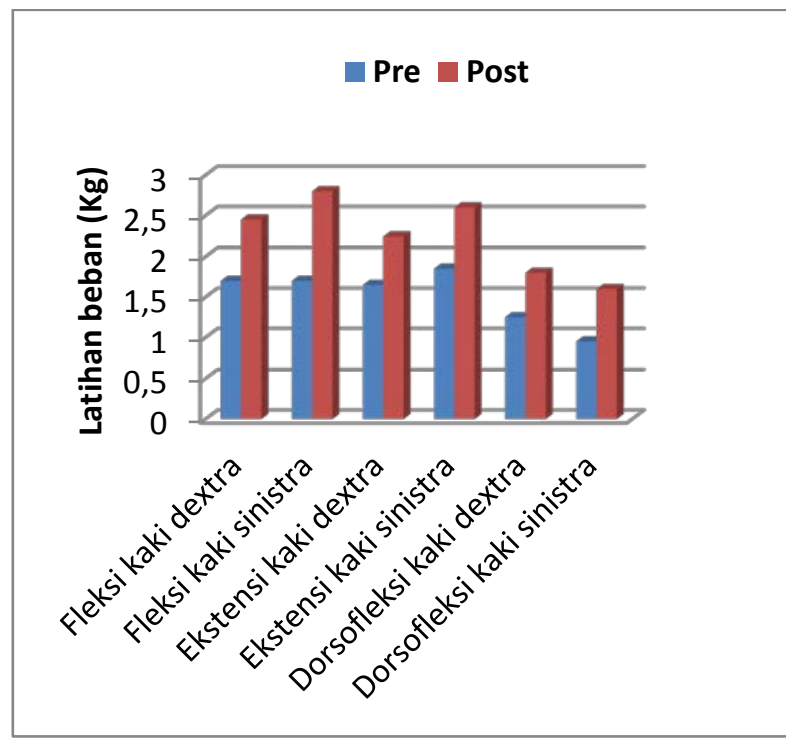

Gambar 11. Rata-rata kekuatan otot kaki pada laki-laki

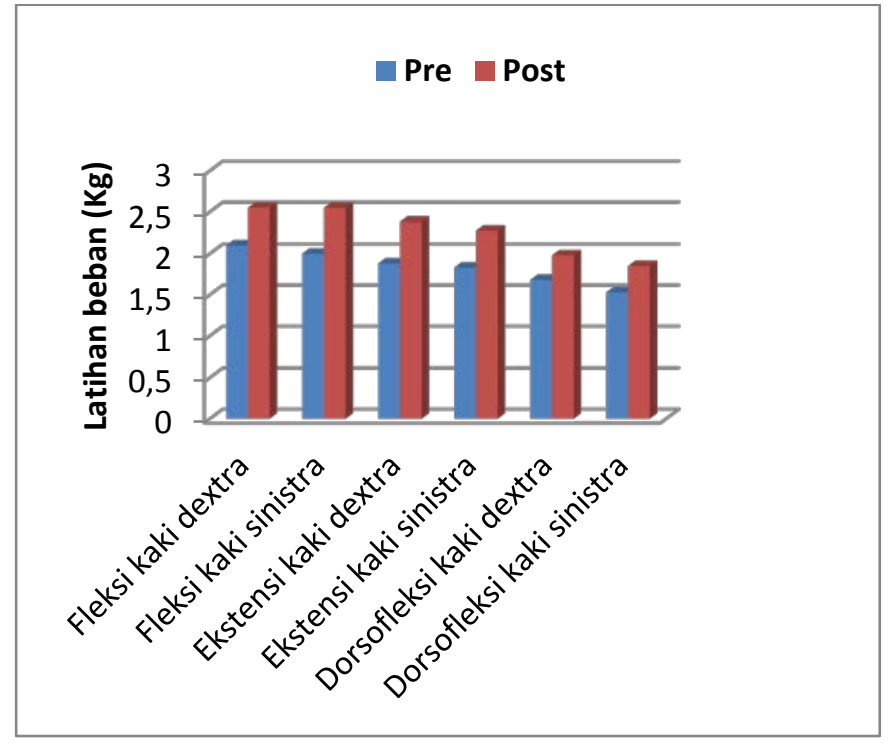

Gambar 12. Rata-rata kekuatan otot kaki pada perempuan

\section{BAHASAN}

Penelitian ini mengenai pengaruh latihan beban terhadap kekuatan otot lansia, dimana terdapat 26 subjek yang memenuhi kriteria inklusi, namun hanya 15 subjek yang mengikuti prosedur penelitian sampai selesai.

Sebagian besar lansia dalam penelitian ini berumur 60-74 tahun berjumlah 8 orang dengan presentase $53,3 \%$ dan yang berumur 75-90 tahun sebanyak 7 orang dengan presentase 46,7\%. Lansia dalam penelitian ini mayoritas perempuan yang berjumlah 10 orang $(66,7 \%)$ dan laki-laki berjumlah 5 orang $(33,3 \%)$.

Berdasarkan data dari Badan Pusat Statistik (BPS) Provinsi Sulawesi Utara (2010), jumlah penduduk sulawesi utara adalah 2.270.596 jiwa, dengan jumlah penduduk lanjut usia lebih dari 60 tahun sebanyak 191.853 jiwa (8,42\%), dimana terdapat 88.180 jiwa (45.96\%) lansia lakilaki dan sebanyak 103.673 jiwa (54.04\%) lansia perempuan. Hal tersebut membuktikan bahwa jumlah lansia perempuan lebih banyak dibandingkan jumlah lansia laki-laki. ${ }^{11}$

Berdasarkan distribusi kekuatan otot terhadap umur didapatkan subjek penelitian tertinggi terdapat pada kelompok umur 6074 tahun sebanyak 53,3\%, sedangkan kelompok umur 75-90 tahun sebanyak 
46,7\% dan dari hasil penelitian distribusi kekuatan otot berdasarkan jenis kelamin didapatkan subjek penelitian tertinggi pada perempuan. Sebuah penelitian menyatakan bahwa kemampuan otot pada laki-laki berpotensi memiliki kekuatan yang lebih besar dari wanita. Namun bukan hanya jenis kelamin yang mempengaruhi kekuatan otot seseorang. Selain jenis kelamin dan usia, kekuatan otot juga dipengaruhi oleh ukuran cross sectional otot, hubungan antara panjang dan tegangan otot pada waktu kontraksi, recruitmen motor unit, tipe kontraksi, jenis serabut otot, ketersediaan energi dan aliran darah, motivasi. Suatu penelitian menunjukkan bahwa terdapat hubungan yang sangat kuat antara fisiologis cross sectional area dan tegangan maksimal pada otot ketika dilakukan kontraksi. Dimana kekuatan otot skeletal manusia dapat menghasilkan kekuatan kurang lebih 3-8 $\mathrm{kg} / \mathrm{cm}^{2}$ pada cross sectional area tanpa memperhatikan jenis kelamin. ${ }^{12}$

Penelitian ini dianalisis menggunakan uji $\mathrm{T}$ berpasangan untuk melihat perbedaan kekuatan otot lansia sebelum melakukan latihan beban dan setelah melakukan latihan beban 3 kali dalam seminggu selama satu bulan

Dari perhitungan statistik uji $\mathrm{T}$ berpasangan didapatkan perbedaan yang signifikan antara kekuatan otot sebelum dan sesudah latihan beban dengan konfidensi interval 95\% ( $\mathrm{p}<0,05)$, kekuatan otot dengan gerakan fleksi siku, ekstensi siku, ekstensi bahu diperoleh nilai signifikan $\mathrm{p}=0,000(\mathrm{p}<0,05)$, gerakan fleksi bahu, abduksi bahu, fleksi kaki sinistra, ekstensi kaki dextra diperoleh nilai signifikan $p=0,001 \quad(p<0,05)$, gerekan dorsofleksi kaki nilai $\mathrm{p}=0,002(\mathrm{p}<0,005)$, gerakan ekstensi kaki sinistra $\mathrm{p}=0,003$ $(p<0,05)$, gerakan fleksi kaki dextra nilai $\mathrm{p}=0,004(\mathrm{p}<0,05)$. Hal ini didukung dengan beberapa penelitian sebelumnya yang menyatakan bahwa latihan beban dapat meningkatkan kekuatan otot.

Penelitian Hanafi menyatakan latihan beban akan meningkatkan kekuatan dan daya tahan. Hal yang sama juga dikemukakan oleh Frank dkk menyatakan bahwa latihan kekuatan pada orang tua lebih dari 60 tahun dapat meningkatkan kekuatan otot dengan meningkatkan massa otot, dan dengan meningkatkan recruitmen motor unit. Massa otot dapat ditingkatkan melalui pelatihan pada intensitas yang sesuai dengan 60\% sampai $85 \%$ dari kekuatan maksimum dan jarang terjadi efek samping. ${ }^{9,13}$

Motor unit merupakan unit fungsional dari system neuro-muskular yang terdiri dari anterior motor neuron (terdiridari axon, dendrit, dancell body) dan serabut otot (terdiri dari slow twitch fiber dan fast twitch fiber). Peningkatan jumlah recruitmen motor unit akan meningkatkan kekuatan otot. Kontraksi otot dengan tenaga besar akan mengaktifkan banyak motor unit dan kontraksi otot dengan tenaga kecil akan mengaktifkan sedikit motor unit. Tidak semua motor unit pada serabut otot aktif pada saat yang sama. Jenis latihan akan mempengaruhi motor unit yang aktif, pada resistance exercise atau latihan untuk meningkatkan kekuatan otot akan mengaktifkan fast twitch fiber sedangkan pada latihan untuk meningkatkan endurance akan mengaktifkan slow twitch fiber. Kekuatan otot juga dipengaruhi oleh factor motivasi. Motivasi yang tinggi akan mempengaruhi kemampuan untuk menghasilkan kekuatan yang maksimal. Oleh karena itu responden harus mau melakukan usaha yang maksimal agar menghasilkan kekuatan yang maksimal. ${ }^{12}$

Beban kerja dalam suatu latihan otot diberikan dalam bentuk massa yang harus dilawan atau dipindahkan oleh gaya kontraksi otot. Dengan memperhatikan besar beban (resistance/intensity), dan ulangan kontraksi otot (repetitions), pembebanan terhadap otot dapat diatur. ${ }^{14}$

\section{SIMPULAN}

Berdasarkan pembahasan di atas dapat diambil kesimpulan bahwa ada pengaruh signifikan latihan beban terhadap peningkatan kekuatan otot lansia. 


\section{SARAN}

1. Dianjurkan agar latihan kekuatan otot yang telah dilakukan tetap dipertahankan agar dapat meningkatkan kekuatan otot lansia.

2. Perlu penelitian lebih lanjut dengan jumlah subjek penelitian yang lebih banyak.

\section{DAFTAR PUSTAKA}

1. Islamiyah, Jafar N, Hadju V. Gaya Hidup Status Gizi dan Kualitas Hidup Manusia Lanjut Usia yang Masih Bekerja. Available from: http://pasca.unhas.ac.id/jurnal/files/9c8 24941af90edc76f726f810473a1ad.pdf

2. Darmajo RB. Geriatri (Ilmu Kesehatan Usia Lanjut). Edisi ke4. Jakarta: Balai Penerbit FKUI; 2011. p.3-10, 35-53.

3. Kemsos. Penduduk Lanjut Usia di Indonesia dan Masalah Kesejahteraannya. Oktober 2007. Available from: http://www.kemsos.go.id/modules.php? name $=$ News \&file $=$ article\&sid $=522$

4. Tegawati LM, Karini MS, Agustin RW. Pengaruh Senam Lansia Terhadap Penurunan Tingkat Depresi pada Orang Lanjut Usia.

5. Junaidi S. Pembinaan Fisik melalui Aktivitas Olahraga Jalan Kaki. 2011. Available from: http://journal.unnes.ac.id/nju/index.php /miki/article/view/1130/1055

6. SilvianiYT. Analisa Hubungan Gangguan Kognitif Terhadap Terjadinya Injury pada Lansia di Panti Sosial Tresna Werdha Budi mulya 4 Margagunan Jakarta. Universitas Muhammadiyah Jakarta. 2012.

7. Ryoto V. Hubungan antara kekuatan otot genggam dengan umur, tingkat kemandirian, dan aktivitas fisik pada lansia wanita klub geriatric terpilih Jakarta utara tahun 2012. Avaibable from:

http://www.google.com/url?sa=t\&rct=j $\& \mathrm{q}=\&$ esrc $=\mathrm{s} \&$ source $=$ web $\& \mathrm{~cd}=1$ \&ved $=0 \mathrm{CBsQFjAA \& url}=\mathrm{http} \% 3 \mathrm{~A} \% 2 \mathrm{~F} \% 2 \mathrm{Fl}$ ib.ui.ac.id\%2Ffile\%3Ffile\%3Ddigital\%
2F20318247-S-

Vergie\%2520Ryoto.pdf\&ei=5WzrVO CRDM6LuASwgoDwCg\&usg=AFQjC NEpFDPpHq2p30bGQju6hjyIPHNlcg \&sig2=wTgwNdMYO1omVwHhucZd aQ\&cad=rja

8. Sriwahyuniati CF. MENJAGA KESEHATAN DAN KEBUGARAN BAGI LANSIA MELALUI BEROLAHRAGA. Available from: http://staff.uny.ac.id/sites/default/files/1 32256205/MENJAGA\%20KESEHAT AN\%20DAN\%20KEBUGARAN\%20 BAGI\%20LANSIA\%20MELALUI\%2 OBEROLAHRAGA.pdf

9. Mayer F, Rosenberger FS, Carlsohn A, Cassel M, Muller S, Scharhag J. The Intensity and Effect of Strength Training in the Elderly. DtschArzteblInt 2011; 108(21):359-64. Available from: http://www.ncbi.nlm.nih.gov/pmc/articl es/PMC3117172/

10.Lee IH, Park SY. Balance Improvement by Strength Training for the Elderly. 2013. Available from: http://www.ncbi.nlm.nih.gov/pmc/articl es/PMC3885846/pdf/jpts-25-1591.pdf

11.Medika AI. Gambaran kadar protein serum orang lanjut usia di balaipenyantunan lanjut usia senja cerah manado[skripsi]. FK UNSRAT. 2012.

12.Lesmana SI. Perbedaan Pengaruh Metode Latihan Beban terhadap Kekuatan dan Daya Tahan Otot Biceps Brachialis Ditinjau dari Perbedaan Gender (studi Komparasi Pemberian Latihan Beban Metode Delorme dan Metode Oxford pada Mahasiswa Fakultas Ilmu Kesehatan dan Fisioterapi. Artikel Fisioterapi Universitas Esa Unggul. Jakarta.

13.Hanafi S. Efektifitas latihan beban dan latihan pliometrik dalam meningkatkan kekuatan otottungkai dan kecepatan reaksi. Ilara. 2010;1:8.

14.Sudarsono NC. Pengaruh Latihan terhadap Kerja Otot Rangka. Artikel Departemen Ilmu Faal FKUI. Jakarta. 